\title{
Rational of consolidation of Regional Rural Banks in India
}

\author{
Effulgence \\ Vol. 17, No. 2 \\ July - December 2019 \\ Rukmini Devi Institute of Advanced Studies \\ E-mail : effulgence@rdias.ac.in, Website : www.rdias.ac.in \\ http://effulgence.rdias.ac.in/user/default.aspx \\ https://dx.doi.org/10.33601/effulgence.rdias/v17/i2/2019/52-62
}

\section{Mr. Shailendra $\operatorname{Singh}^{1} \bowtie$ \\ Dr. Megha Aggarwal ${ }^{2}$}

\begin{abstract}
The Regional Rural Banks (RRBs) came in to existence as an institutional source for making financial assistance available to the rural areas as the commercial banks could not serve the desired purpose in view of the financial viability as well the inadequate infrastructure facilities that was hindrance for expansion of commercial banks in the remote rural areas. The RRBs were established in 1975 starting from October 2, 1975. The main objective of promoting RRBs was to facilitate banking reach to the rural segments and to provide them adequate credit facilities and thereby improve their living conditions. There was fast expansion of RRBs and within the span of 15 years, by 1990-91, the number of RRBs in India reached to 196. Another important aspect of establishing the RRBs was to operate them at low cost in view of their local presence and regional in character in view of their operations being managed by locally employed people. However, the concept low cost operation could not sustain as there was demand by the RRB staff for "equal pay for equal work" and with the intervention of the legal framework, the salaries of $R R B$ staff were brought at par with the nationalized banks. This made the operational cost of RRBs much higher. The balance sheet of many RRBs started showing losses and their viability posed a serious question. This received the attention of policy makers and a strong need was felt to consolidate the functioning of RRBs by way of mergers to bring more efficiency in terms of financial performance and sustainability in the long run. Accordingly the merger of RRBs got momentum in the country resulting reducing the number of RRBs from 196 to just 56. This paper assesses the impact of merger on operational efficiency of the RRBs.
\end{abstract}

Keywords: Financial viability, merger, operational efficiency, viability, investments, profits.

\section{INTRODUCTION}

$\mathrm{T}$ he era of social transformation of banking sector in India has completed five long decades as the process of socialization in banking sector was initiated in 1967 followed by nationalization of banks in 1969. During these five decades, the banking industry has undergone various facets starting from

1. Research Scholar, Banasthali Vidyapith, Rajasthan, India

2. Assistant professor, Faculty of Management Studies-WISDOM, Banasthali Vidyapith, Rajasthan, India 
mass banking to focused banking, manual banking to IT banking, social banking to corporate banking and so on. Similarly, there have been many changes in the organizational structure of banking system where the process of transformation and consolidation received importance right from the year1991 as a part of reform process. During the period of post financial sector reforms, the banking operations and strategies were focused to bring professionalism and thereby contributing more effectively to the social and economic growth. A quick review of the past on various happenings and developments in the banking sector reveals multidimensional changes in banking operations over the past five decades. The banking business has changed multifold from bare minimum business of just Rs. 82.45 billion in 1970 to Rs. 205,400 billion at the end of March 2018. There have been several and significant changes in all the spheres and activities in the banking sector due to added focus given to bring information technology that made the banking operations much easier and accessible anytime and anywhere. Eve people in remote rural areas banks on finger tips leave metropolitan and urban centers. The position of important banking parameters related to commercial banks in India is presented in the following Table1:

Table1:

\begin{tabular}{|c|l|c|c|}
\hline S. No. & \multicolumn{1}{|c|}{ Parameters } & $\mathbf{1 9 7 0}$ & $\mathbf{2 0 1 7}$ \\
\hline 1 & No. of Banks & 73 & 156 \\
\hline 2 & No. of Branches & 8,262 & $1,50,672$ \\
\hline 3 & Deposits & 46.46 & $1,08,051$ \\
\hline 4 & Loans \& Advances & 35.99 & 78,817 \\
\hline 5 & Total ATMs \& POS & Nil & $2,10,000$ \\
\hline 6 & Total Credit cards (million) & Nil & 24.57 \\
\hline 7 & Total Debit cards (million & Nil & 661.8 \\
\hline
\end{tabular}

Source: RBI Annual Report and RBI Website

The phases of banking growth could be broadly categorized into five broad categories in the post Nationalization era viz. Expansion phase (19701985), Diversification phase (1985-1990), Banking reform phase (1991-2000), Technology, Consolidation and operational efficiency phase (2001-2010) and Digital banking (2011 onwards).

\section{Emergence of Regional Rural Banks}

The history of establishment of Regional Rural (RRBs) in India goes back to 1975 when the government implemented 20 point Economic Program for the weaker sections. The need was felt to expand the banking operations in the remote rural areas so as to extend the credit to rural segment which were hitherto deprived with such facilities. The RRBs were promoted through a separate act in 1975. The major objective behind creating an additional tier in the credit delivery system was to extend sufficient credit to the neglected rural segment mainly covering the weaker sections of the rural segment for various activities both, the agriculture and allied activities along with small, rural and cottage industries. The RRBs were set up on the recommendations of a working group appointed by the Banking Commission. The working group after considering and analyzing various aspects of rural credit delivery system recommended for establishing a separate financial institution exclusively to cater to the financial requirements of rural sector and recommended a low cost model of operation. Based on the recommendations, the government set up the Regional Rural Banks through a separate act known as Regional Rural Bank Act 1976. 
The following were the broad functions which were required to be performed by the RRBs.

a) Develop an additional and exclusive channel for extending smooth flow of credit to meet increased demand of rural credit from institutional sources and thus minimizing their dependence on informal credit system.

b) To extend credit facilities to different types of credit, cooperative and marketing societies involved at grass root level and serving for the rural development cause to make them more instrumental in the rural growth process.

c) To minimize the cost of credit by bringing down the operational cost.

d) To expand the banking services in remote rural areas where commercial banks could not make an entry due to poor infrastructure and other facilities as there were large number of centers identified for banking expansion.

e) The RRBs were also expected to involve locally and initiate measures to bring up living standard as well the quality of life in the rural areas.

The very concept of establishing RRBs was to operate them at the low cost as compare dto commercial banks. However, this concept lost the significance as the employees demanded equal pay for equal work. To make them viable and self sustained, many measures were initiated including permitting them to lend on commercial lines and bringing their existence at urban centers. Even after these measures, the viability of these banks posed a big challenge. The Vyas committee that was constituted to study and suggest the operational and organizational structure suggested consolidation of RRBs to make them viable and also to contribute in a big way in the growth process. In view of the recommendations of the Vyas Committee, NABARD initited the process of consolidation of RRBs in phased manner beginning from 2005. By the end of 2013, the number of RRBs was brought down to 64 from 196. Further, there are 56 RRBs as of now operating in India.

\section{LITERATURE REVIEW}

The Basu Committee (1996) constituted for suggesting framework for Revamping of Regional Rural Banks supported the introduction of Prudential Norms for Regional Rural Banks with required modifications in view of the nature of their functions. The committee also suggested to broadbase the selection process of chairman of RRBs. In addition, the committee was also of the view that some of the RRBs may not stand viable if they continue operating independently. Therefore, the merger of such banks could be the only solution.

Another committee known as Thingalaya Committee (1997) also recommended that the cases of very weak RRBs need to be examined separately to assess the possibilities of their liquidation. In such a scenario, the merger could take place with neighboring RRBs. The committee was also of the strong opinion that Board of Directors of RRBs be given required functional autonomy to ensure that the bank functions keeping viability in view and design and implement strategies accordingly. They also felt strengthening the spirit of professionalism in managing the overall efficiency of the working of RRBs.

In 2004, the Vyas Committee II suggested two different models i.e. a Zonal Bank for RRBs in the North-East and Rural Banks at state level for the remaining part of the country. Under this the committee suggested all RRBs of a sponsor bank in a state would be amalgamated into a single unit in that state at the first stage. While in the second stage, state-wise consolidation and formation of state level rural banks may take place. The committee was also of the view that the restructured state/zonal level RRBs may explore possibilities to raise cost effective resources through the instruments like, issue of Certificates of Deposits.

Azeem Ahmad Khan (2011) in his study on "Merger and Acquisitions in the Indian Banking Sector in Post Liberalization Regime" assessed the impact of 
merger in the Indian banking sector. The researcher analyzed two cases for the study as sample to examine if mergers led to a profitable situation. The results of this study suggested that the efficiency and performance of banks have increased after mergers.

Another study conducted by Devarajappa S (2012), on "Mergers in Indian banks involving a study of merger between HDFC bank and Centurion Bank of Punjab." This study concludes that the return on equity, debt -equity ratio and Gross Profit margin shows improvement after the merger. The researcher used t-test for analyzing the pre and post-merger performance of banks where finding suggested that financial performance of the banks showed improvements after merger.

In 2012, Tasleema M Jorum and Sujata S Mali conducted a study on Performance of Regional Rural Banks after Amalgamation in India. This study observed that the performance of RRBs in India improved during the post amalgamation period, even though number of RRBs reduced but their profitability increased. There have been improvements in terms of deposit mobilization, credit deployment, recovery performance and decreased level of NPAs.

Madan Mohan Dutta, Suman Kumar Dawn (2012), in a study on "Mergers and Acquisition in Indian Banks after Liberalisation, concluded that consolidation in the banking sector in India is inevitable as mergers have become the most acceptable route for growth and stability in the banking sector.

Monika Aggarwal (2012), had undertaken a study on "Motives for Consolidation in Indian Banking Sector", and observed that the forces like, deregulation, advancement in technology, privatization, globalization, financial crisis etc. have changed the financial landscape. Further, competition, consolidation and convergence have received focus now. According to the study, consolidation leads to synergies like cost reduction, enhanced market base, increased geographical spread and technological automation. This in turn strengthens the system and reduces vulnerability to macroeconomic shocks.

A study conducted on mergers and acquisitions prospects of Indian Banks by Smita Meena, Pushpender Kumar (2014) indicates that the pre and post- Mergers and Acquisitions of selected banks in India do not indicate significant changes in profitability ratio, except few banks performing well. This study concludes that even after ten years of merger, the firms could not improve their performance. However, overall results indicate that mergers led to higher level of cost efficiencies for the merged banks. On the other hand, merger between distressed and strong banks did not yield much gains to participating banks.

Parveen Kumari (2014), conducted a study on "Mergers and Acquisitions in Indian Banking SectorA Strategic Approach". This study concludes that all the merged entities after mergers and acquisitions are continuously growing rather than before the merger. There is increase in no. of branches and ATMs as well as in deposit amount, their net profit and worth.

Gurbaksh Singh, Sunil Gupta (2015), conducted a study on "An Impact of Mergers and Acquisitions on Productivity and Profitability of Consolidation Banking Sector in India". This study evaluated the productivity and profitability comprising fourteen ratios and compared between the pre and postmerger of selected public and private sector bank. The researchers used appropriate statistical tools to analyze the financial pyramid of banks pre and post merger and observed increased financial performance of banks.

Komal Gupta (2015), in her study on "Mergers and Acquisitions in the Indian Banking Sector: finds that in the post-merger era, most of the financial parameters have shown significant improvements. The study observed positive impact of mergers and 
acquisitions on the financial performance of the banks.

A study on "Impact of mergers on Indian Banking Sector: A comparative study of Public and Private Sector merged Banks" conducted by Tamragundi, Devarajappa (2016), concluded mergers could be considered as a useful strategy to achieve financial performance of commercial banks. This is possible through achieving economies of scale, competitiveness, and increased efficiency and the market share.

\section{A report of FICCI (2016) on Bank Consolidation} also concludes that the consolidation process among banks has been instrumental in bringing synergies, efficiency, cost saving and economies of scale. The study also suggests that banks should focus to mitigate exposures in areas related to inter connectivity, the market, regulatory compliance, credit quality, etc. The study supports consolidation with the objective of strengthening the bank's bargaining power, efficiencies in the costs, improve supervision and corporate governance across the banking system.

A study on mergers and acquisitions in the banking sector in international perspective conducted by Ruchita Sharma and Janaki Singh (2018) compared Indian and International studies and observed that the majority of research work on Banks in the area of M\&As mainly concentrated in USA and Europe. However, a few studies were conducted in other countries in the recent times. According to this study, Indian research has not been able to keep up with the International standards in the field of Banks' M\&As.

\section{Objectives of the Study}

The following are the broad objectives of this study

i) To analyze the performance of RRBs during the phases of merger periods.

ii) To analyze the financial performance of RRBs after the consolidation process.

iii) To analyze capital structure and its relevance on financial efficiency.

\section{METHODOLOGY}

The study is based on secondary data available from NABARD, RBI and Annual Reports. The data was segregated and analyzed on different parameters considering their operations and profitability parameters to assess the impact during the period. The important relevant financial parameters were taken into account to assess the performance of RRBs to establish a case if the mergers of RRBs bring efficiency.

The process of consolidation of RRBs was initiated in the phased manner beginning since 2005. The number of RRBs from 196 (2005) were brought down to 56 (2018). The very objective of consolidation was focused for improving operational and financial performance so as to make them self sustained as majority of them were running in losses. Along with the amalgamation, technology also played an important role and the very operational mechanism of RRBs show a tremendous changes over a period of time. This has brought efficiencies in many terms. The following table represents the performance of RRBs on selected parameters. 
Table 2: Branch Expansion of RRBs

\begin{tabular}{|c|c|c|c|c|c|c|}
\hline Year & $\begin{array}{c}\text { No. of } \\
\text { RRBs }\end{array}$ & $\begin{array}{c}\text { No. of } \\
\text { District }\end{array}$ & \% Growth & $\begin{array}{c}\text { No. of } \\
\text { Branches } \\
\text { opened }\end{array}$ & $\begin{array}{c}\text { No. of } \\
\text { Branches }\end{array}$ & \% Growth \\
\hline 2001 & 196 & 484 & - & & 14,311 & - \\
\hline 2005 & 196 & 523 & 0.97 & 39 & 14,484 & 0.27 \\
\hline 2010 & 82 & 618 & 0.32 & 299 & 15,480 & 1.97 \\
\hline 2015 & 56 & 644 & 0.31 & 942 & 20,024 & 4.94 \\
\hline 2016 & 56 & 644 & 0.00 & 1,822 & 20,904 & 4.39 \\
\hline
\end{tabular}

Source: Annual reports of NABARD, from March 2001 to 2016

Table 2 shows that the number of RRBs decreased to 56 in the year 2015-16 in comparison to 196 in the year 2001-02, the decrease happened after the amalgamation that started in 2005 and is still in process. The No. of branches and district coverage increased significantly from 14,311 branches covering 484 districts with 196 RRBs in 2001-02 to 20,904 branches covering 644 districts with 56 RRBs in $2015-16$ which reflects the growth of $4.39 \%$. The increase in the number of branches over the period is 1.46 times and the district coverage is 1.33 times.

Table 3: Deposits, Loans/Advances, Credit Deposit Ratio

\begin{tabular}{|c|c|c|c|c|c|}
\hline Year & $\begin{array}{l}\text { Deposits } \\
\text { (Rs. In crore) }\end{array}$ & $\begin{array}{l}\text { Increment in } \\
\text { deposits } \\
\text { (Rs. In crore) }\end{array}$ & $\begin{array}{l}\text { Loans/Advances } \\
\text { (Rs. In crore) }\end{array}$ & $\begin{array}{l}\text { Increment in } \\
\text { loans/Advances } \\
\text { (Rs. In crore) }\end{array}$ & $\begin{array}{c}\text { Credit } \\
\text { deposit ratio }\end{array}$ \\
\hline 2001 & $38,277.78$ & - & $15,815.80$ & - & 41.32 \\
\hline 2005 & $62,143.00$ & $5,793.00$ & $32,870.03$ & $6,757.03$ & 52.89 \\
\hline 2010 & $1,45,034.00$ & $24,845.05$ & $82,819.10$ & $15,017.00$ & 57.10 \\
\hline 2015 & $2,73,018.00$ & $33,524.00$ & $1,80,955.00$ & $21,549.00$ & 66.28 \\
\hline 2016 & $3,15,048.00$ & $42,030.00$ & $2,07,279.00$ & $26,324.00$ & 65.79 \\
\hline
\end{tabular}

Source: Annual reports of NABARD, from March 2001 to 2016

Table 3 shows that deposits of RRB increased from Rs. $38,277.78$ crore in 2001 to Rs. 3,15,048 crore in 2016, registering a growth rate of $15.39 \%$.The advances and loans given by all the RRBs in country increased from Rs. 15815.80 crore in 2001 to Rs. 2,07,
279.00 crore in 2016 , registering a growth of $14.55 \%$.

The credit deposit ratio increased from $41.32 \%$ in 2001 to $65.79 \%$ in 2016 .

Table 4: Branch \& Staff Productivity of RRBs in India

\begin{tabular}{|c|c|c|c|c|c|}
\hline Year & $\begin{array}{c}\text { Deposits + } \\
\text { Advances } \\
\text { (Rs. In crore) }\end{array}$ & Branches & $\begin{array}{c}\text { Per Branch } \\
\text { productivity }\end{array}$ & Staff & $\begin{array}{c}\text { Per-Staff } \\
\text { Productivity }\end{array}$ \\
\hline $2001-02$ & $63,168.70$ & 14,390 & 4.39 & 60,739 & 1.04 \\
\hline $2005-06$ & $1,11,041.00$ & 14,489 & 7.66 & 68,970 & 1.61 \\
\hline $2010-11$ & $2,65,149.77$ & 15,938 & 16.64 & 70,145 & 3.78 \\
\hline $2014-15$ & $4,53,973.00$ & 20,024 & 22.67 & NA & NA \\
\hline $2015-16$ & $5,22,327.00$ & 20,904 & 24.99 & NA & NA \\
\hline
\end{tabular}

Source: Annual reports of NABARD, from March 2001 to 2016 
Table 4 highlights that business of RRBs in India increased from Rs. $63,168.70$ crore in 2001-02 to Rs. $5,22,327.00$ crore in 2015-16, recording an increase of 8.26 times. The per branch productivity of business of RRBs increased from 4.39 crore in 2001-02 to 24.99 crore in 2015-16, recording an increase of 5.69 times. The per employee productivity of business also increased from Rs. 1.04 crore in 2001-02 to Rs. 4.98 crore in 2013-14, recording an increase of 4.79 times.

Table 5: Recovery Performance of RRBs in India

\begin{tabular}{|c|c|c|c|c|}
\hline Year & $\begin{array}{c}\text { Demand } \\
\text { (Rs. In crore) }\end{array}$ & $\begin{array}{c}\text { Collection } \\
\text { (Rs. In crore) }\end{array}$ & $\begin{array}{c}\text { Balance } \\
\text { (Rs. In crore) }\end{array}$ & $\begin{array}{c}\text { Recovery } \\
\text { (Rs. In crore) }\end{array}$ \\
\hline 2001 & $9,617.93$ & $6,789.59$ & $2,828.34$ & 70.59 \\
\hline 2005 & $19,370.17$ & $15,755.18$ & $3,614.99$ & 81.34 \\
\hline 2010 & $42,567.32$ & $34,092.16$ & $8,475.16$ & 80.09 \\
\hline 2015 & NA & NA & NA & 79.49 \\
\hline 2016 & NA & NA & NA & 82.51 \\
\hline
\end{tabular}

Source: Annual reports of NABARD, from March 2001 to 2016

Table 5 shows the recovery percentage during 2001-16 from $70.59 \%$ in 2001 to $82.51 \%$ in 2016 . It is clear from the table that RRBs are facing difficulties in recovering the loan amount; the recovery performance of RRBs is not satisfactory.

Table 6: Components of Total Capital/Fund

\begin{tabular}{|c|c|c|c|}
\hline Year & $\begin{array}{c}\text { Owned Funds } \\
\text { (Rs. In crore) }\end{array}$ & $\begin{array}{c}\text { Borrowed Funds } \\
\text { (Rs. In crore) }\end{array}$ & $\begin{array}{c}\text { Total Funds } \\
\text { (Rs. In crore) }\end{array}$ \\
\hline $2001-02$ & $4,059.00$ & $4,524.00$ & $8,583.00$ \\
\hline $2005-06$ & $6,646.59$ & $7,302.59$ & $13,949.18$ \\
\hline $2010-11$ & $13,838.92$ & $26,490.80$ & $40,329.72$ \\
\hline $2014-15$ & $25,084.00$ & $59,422.00$ & $84,506.00$ \\
\hline $2015-16$ & $27,716.00$ & $48,110.00$ & $75,826.00$ \\
\hline
\end{tabular}

Source: Annual reports of NABARD, from March 2001 to 2016

Table 6 reveals the year wise growth in total capital i.e. growth in owned funds and borrowed funds of RRBs in India. The figure of borrowed funds increased from Rs. 4,524 crore in 2001-02 to Rs. 48,110 crore in 2015-16 and the owned funds increased from Rs. 4,059 crore in 2001-02 to Rs. 27,716 crore in 2015-16.

Table 7: Growth in Investment in India

\begin{tabular}{|c|c|c|c|}
\hline Year & $\begin{array}{c}\text { Total Investment } \\
\text { (Rs. In crore) }\end{array}$ & $\begin{array}{c}\text { Increase over } \\
\text { previous year } \\
\text { (Rs. in crore) }\end{array}$ & $\begin{array}{c}\text { \% increase over } \\
\text { previous year }\end{array}$ \\
\hline $2001-02$ & $30,531.64$ & - & - \\
\hline $2005-06$ & $41,182.45$ & $4,414.79$ & 12.01 \\
\hline $2010-11$ & $86,510.44$ & $7,131.28$ & 8.98 \\
\hline $2014-15$ & $1,62,781.00$ & $23,150.00$ & 16.58 \\
\hline $2015-16$ & $2,10,936.00$ & $48,155.00$ & 29.58 \\
\hline
\end{tabular}

Source: Annual reports of NABARD, from March 2001 to 2016 
Table 7 shows that the amount of investment of RRBs in India increased from Rs. 30,531.64 crore in 2001-02 to Rs. 2,10,936 crore in 2015-16 registering the growth of $29.58 \%$.

Table 8 Return on Investment and profit as percentage of volume of Business

\begin{tabular}{|c|c|c|c|c|c|}
\hline Year & $\begin{array}{c}\text { Net Profit } \\
\text { (Rs. in crore) }\end{array}$ & $\begin{array}{c}\text { Volume of } \\
\text { Business } \\
\text { (Rs. in crore) }\end{array}$ & $\begin{array}{c}\text { Profit as \% of } \\
\text { volume of } \\
\text { Business }\end{array}$ & $\begin{array}{c}\text { Investment } \\
\text { (Rs. in crore) }\end{array}$ & $\begin{array}{c}\text { Return on } \\
\text { Investment } \\
\text { (\%) }\end{array}$ \\
\hline $2001-02$ & 600.62 & $3,520.85$ & 17.06 & $30,531.64$ & 1.97 \\
\hline $2005-06$ & 617.13 & $4,009.74$ & 15.39 & $41,182.45$ & 1.50 \\
\hline $2010-11$ & $2,394.43$ & $12,306.53$ & 19.09 & $86,510.44$ & 2.72 \\
\hline $2014-15$ & $2,745.00$ & $24,011.00$ & 11.43 & $1,62,781.00$ & 1.69 \\
\hline $2015-16$ & $2,435.00$ & $26,685.00$ & 9.12 & $2,10,936.00$ & 1.15 \\
\hline
\end{tabular}

Source: Annual reports of NABARD, from March 2001 to 2016

Table 8 shows that investments increased from Rs. 30,531.64 crore in 2001-02 to Rs. 2,10, 936.00 crore in 2015-16, but there is no constant improvement in ROI as it was 1.97\% in 2001-02 and reached to its minimum level of $1.15 \%$ in $2015-16$.

Table 9: Percentage of Gross NPA to Loans of RRBs

\begin{tabular}{|c|c|c|c|}
\hline Year & $\begin{array}{c}\text { Gross Loan } \\
\text { (Rs. in crore) }\end{array}$ & $\begin{array}{c}\text { Gross NPAs } \\
\text { (Rs. in crore) }\end{array}$ & \% to Total \\
\hline 2001 & $15,815.00$ & 2,980 & 18.84 \\
\hline 2005 & $32,870.03$ & 2,804 & 8.53 \\
\hline 2010 & $82,819.10$ & 3,081 & 3.72 \\
\hline 2015 & $1,80,955.00$ & 11,129 & 6.15 \\
\hline 2016 & $2,07,279.00$ & 13,369 & 6.45 \\
\hline
\end{tabular}

Source: Annual reports of NABARD, from March 2001 to 2016

Table 9 concludes that the gross NPA of all RRBs decreased constantly in percentage, the Gross NPA increased from Rs. 2,980 crore in 2001 to Rs. 13,369 crore in 2016. Table also shows that the Gross NPA in percentage is declining from $18.84 \%$ in 2001 to $6.45 \%$ in 2016. While 32 RRBs reported Gross NPAs less than 5\% in 2015, 27 RRBs have reported Gross NPA less than 5\% in 2016.

Table 10: Profit position of RRBs in India

\begin{tabular}{|c|c|c|c|c|c|c|c|c|}
\hline Year & $\begin{array}{c}\text { No. of } \\
\text { RRBs }\end{array}$ & $\begin{array}{c}\text { RRBs } \\
\text { in } \\
\text { Profit }\end{array}$ & $\begin{array}{l}\text { Profit } \\
\text { Amount } \\
\text { (Rs. in } \\
\text { crore) }\end{array}$ & $\begin{array}{c}\text { RRBs } \\
\text { in } \\
\text { Loss }\end{array}$ & $\begin{array}{c}\text { Amount } \\
\text { of Loss } \\
\text { (Rs. in } \\
\text { crore) }\end{array}$ & $\begin{array}{c}\text { Net } \\
\text { Profit }\end{array}$ & $\begin{array}{c}\text { RRBS with } \\
\text { Accumulated } \\
\text { Losses }\end{array}$ & $\begin{array}{c}\text { Accumulated } \\
\text { Losses }\end{array}$ \\
\hline $\begin{array}{c}2001- \\
02\end{array}$ & 196 & 170 & 676.48 & 26 & 75.86 & 600.62 & NA & $2,792.59$ \\
\hline $\begin{array}{c}2005- \\
06\end{array}$ & 133 & 111 & 807.79 & 22 & 66,301 & 617.13 & 58 & $2,636.85$ \\
\hline $\begin{array}{c}2010- \\
11\end{array}$ & 82 & 75 & $2,420.75$ & 7 & 71.32 & $2,349.43$ & 23 & $1,532.39$ \\
\hline $\begin{array}{c}2014- \\
15\end{array}$ & 56 & 51 & $2,921.00$ & 5 & 176.00 & $2,745.00$ & 8 & $1,072.00$ \\
\hline $2015-$ & 56 & 51 & $2,556.00$ & 5 & 121.00 & $2,435.00$ & 8 & 1.030 .00 \\
16 & & & & & & & & \\
\hline
\end{tabular}

Source: Annual reports of NABARD, from March 2001 to 2016 
Table 10 illustrates that net profit position of RRBs raised from Rs. 600.02 crore in 2001-02 to Rs. 2,435.00 crore in 2015-16 indicating that more than 91.07\% RRBs are operating on profitable line. The number of loss making RRBs have reduced from 26 in 2001-02 to 5 in 2015-16. The accumulated loss making RRBs have reduced to 8 and amount of accumulated loss also reduced to Rs. 1,030 crore in 2015-16.

\section{Performance of Regional Rural Banks, During the period (2002- 2017)}

(Year Wise Amount: Rs. in crore)

Table 11

\begin{tabular}{|c|c|c|c|c|c|c|c|}
\hline Year & Profit & Loss & $\begin{array}{c}\text { Accumulated } \\
\text { Loss }\end{array}$ & Year & Profit & Loss & $\begin{array}{c}\text { Accumulated } \\
\text { Loss }\end{array}$ \\
\hline 2002 & 676.48 & 92 & 2793 & 2010 & 2420.7 & 71.3 & 1775.06 \\
\hline 2003 & 699.93 & 214 & 2694.06 & 2011 & 1886.1 & 28.8 & 1532.39 \\
\hline 2004 & 733.97 & 154 & 2752.25 & 2012 & 2275 & 0 & 1332.57 \\
\hline 2005 & 902.6 & 190 & 2715.01 & 2013 & 2694 & 0 & 1091 \\
\hline 2006 & 807.79 & 301 & 2636.85 & 2014 & 2921 & 0 & 948 \\
\hline 2007 & 1383.6 & 55.5 & 2759.49 & 2015 & 2781 & 177 & 1069 \\
\hline 2008 & 1823.5 & 35.9 & 2624.22 & 2016 & 2206 & 188 & 1050 \\
\hline 2009 & 2514.8 & 5.65 & 2299.98 & 2017 & 2604 & 387 & 1147 \\
\hline
\end{tabular}

Source: NABARD, Annual Reports

To analyze the impact of consolidation on RRB's performance, paired $t$ test is applied on the profits ( taken as proxy of financial performance). For the application of paired $t$ test the data is divided in two samples : one from 2002 to 2009 and and other from 2010 to 2017.

\section{$\underline{\text { Rationale behind sample selection }}$}

As it is quite evident from table 11 that there is an increase in amount of profits from 2008 -2010 (from Rs.1823.5 cr to Rs. 2420.7 cr). Hence, 2009 is taken as a break year.

\section{$\underline{\text { Results of Paired t test }}$}

Null hypothesis: there is no significant difference in the performance between the sample periods Alternate hypothesis: there is significant difference in the performance between the sample periods. Level of significance $5 \%$

Table 12 t-Test: Paired Two Sample for Means

\begin{tabular}{|l|c|c|}
\hline & $\mathbf{2 0 0 2 - 0 9}$ & $\mathbf{2 0 1 0 - 1 7}$ \\
\hline Mean & $\mathbf{1 1 9 2 . 8 3 4}$ & $\mathbf{2 4 7 3 . 4 7 5}$ \\
\hline Variance & 447764.6 & 117035.4 \\
\hline Observations & 8 & 8 \\
\hline Pearson Correlation & 0.146059 & \\
\hline Df & 7 & \\
\hline $\mathrm{p}$ value & $\mathbf{0 . 0 0 1 3 4 9 ^ { * * }}$ & \\
\hline
\end{tabular}

(author's calculation; ** significant at 5\%) 
Since, $\mathrm{p}$ value $<.05$ ( see table 12 ), hence we reject null hypothesis and conclude that there is significant difference in the financial performance during the sample periods.

Further, one tail one sample $t$ test is applied to assess the performance of the RRB"s but taking accumulated losses as proxy. The test is applied on data of sample period II ( 2010 to 2017)

Null hypothesis : $\mu=2659$

Alternate Hypothesis: $\mu<2659$

Here $\mu$ is average of accumulated losses in sample period II.

Table 13

\begin{tabular}{|l|c|c|c|}
\hline $2010-2017$ & $\mathrm{~N}$ & Mean & Std. Deviation \\
\hline Accu losses & 8 & $\mathbf{1 2 4 3 . 1 2 7 5}$ & 283.27853 \\
\hline
\end{tabular}

Table 14 One-Sample Test ( one tail)

\begin{tabular}{|l|c|c|c|c|}
\hline \multirow{2}{*}{} & \multicolumn{3}{|c|}{ Test Value $=2660$} \\
\cline { 2 - 5 } & & & & \\
\hline Accu losses & -14.147 & 7 & Sig. (2-tailed) & Mean Difference \\
\hline
\end{tabular}

(author's calculation; ${ }^{* *}$ significant at $5 \%$ )

Since, $\mathrm{p}$ value $<.05$ ( see table 14), hence we reject null hypothesis and conclude that the mean of accumulated losses of the sample period II is less than the test value 2660 (which is average of accumulated losses of sample period I)

\section{FINDINGS}

This study reveals that out of 196 RRBs in 1995, 164 banks were running under the losses. The merger process started in the beginning of 2001 and by the end of 2005, the number of RRBs was brought down to 133 and at the end of 2006, there were only 22 RRBs that were operating under the losses. Further, as at the end of 2015-16, there were only 5 banks that were in red out of 56 banks. By the end of March 2017, the number of los making RRBs was 7 out of a total of 56 RRBs as on that date. Therefore, it is very much evident that the very purpose of consolidation of RRBs in India for turning them from loss making to profit making was achieved. This is during the merger and consolidation process only that number of loss making RRBs was brought down significantly due to the variety of reasons, the major being the operational and administrative costs. Further, the capital structure of RRBs also posed a big challenge prior to consolidation of RRBs. There is a voluminous increase in the total funds available with RRBs. Besides, their performance in terms of asset management in reducing the level of nonperforming assets, increase in credit-deposit ratio, return on investments etc. are the indicators of their improved performance in the post consolidation process.

\section{CONCLUSION}

From the data analysis, it is evident that the merger of RRBs has helped to improve financial performance of the RRBs as whole in terms better per branch business, business per employee, increased return on investments, reduction in the level of non-performing assets, increase in per staff productivity, increase in the level of owned funds under the capital component and reduction of debt funds. These performance indicators show that the merger helps in augmenting the financial performance of banks. This conclusion is arrived on 
the basis of the fact that financial performance indicators witnessed better and improved performance in phased manner during the period. It is on account of the fact that in 2001 the number of RRBs was 198 that came down to 57 in 2016 in phased manner. With the decrease in the number of banks, the efficiency of financial parameters improved. The existing literature available on merger of commercial banks also support this view.

\section{REFERENCES}

1) Azeem Ahmad Khan (2011), “Merger and Acquisitions (M\&As) in the Indian Banking Sector in Post Liberalization Regime". International Journal of Contemporary Business StudiesVol: 2, No: 11. November, 2011.

2) Devarajappa $S$ (2012), "Mergers In Indian Banks: A Study on Mergers of HDFC Bank Ltd and Centurion Bank of Punjab Ltd." International Journal of Marketing, Financial Services \& Management Research, Vol.1 Issue 9.

3) Tasleema M Jorum and Sujata S Mali (2012), A study on "Performance of Regional Rural Banks after Amalgamation in India: Progress and Prospects", Artha J Soc Sci, 11, March 2012.

4) Madan Mohan Dutta, Suman Kumar Dawn (2012), "Mergers and Acquisition in Indian Banks after Liberalisation: An Analysis". Indian Journal of Commerce \& Management Studes, Vol. III, Issue 1.

5) Monika Aggarwal (2012), “Motives for Consolidation in Indian Banking Sector", International Journal of Marketing and Technology", Vol. 2, Issue 9.

6) Smita Meena, Pushpender Kumar (2014), "Mergers and Acquisitions Prospects: Indian Banks study". International Journal of Recent Research in Commerce Economics and Management, Vol. 1, Issue 3, pp: (10-17).

7) Parveen Kumari (2014), "Mergers and Acquisitions in Indian Banking Sector- A Strategic Approach". Global Journal of Finance and Management, Volume 6, Number 3 pp. 217222.
8) Gurbaksh Singh, Sunil Gupta (2015), “An Impact of Mergers and Acquisitions on Productivity and Profitability of Consolidation Banking Sector in India".

9) Abhinav International Monthly Refereed Journal of Research in Management \& Technology, Volume 4, Issue 9.

10) Komal Gupta (2015), "Mergers and Acquisitions in the Indian Banking Sector: A Study of Selected Banks". International Journal of Advanced Research in Management and Social Sciences. Vol. 4 No. 3.

11) A.N.Tamragundi, Devarajappa (2016), “Impact of mergers on Indian Banking Sector: A comparative study of Public and Private Sector merged Banks". Acme Intellects International Journal of Research in Management, Social Sciences \& Technology, Vol- 13 No. 13 Jan 2016.

12) FICCI -Bank Consolidation: Way Forward (2016), FICCI Economic Affairs and Research Division. December 28, 2016.

13) Ruchita Sharma \& Janaki Singh (2018), Journal of Banking, Information Technology and Management, Volume 15 No. 1 January-June 2018. 